\title{
SOCIO-CULTURAL INFLUENCES ON CHILD LABOUR ISSUE IN ACEH PROVINCE INDONESIA
}

\author{
By: \\ YENNI ROSANA, RICHARD CHAUVEL, SIEW FANG LAW \\ Universitas Dehasen Bengkulu, Melbourne University, Victoria University
}

\begin{abstract}
This research investigates the socio-cultural meaning of child labour in Aceh Province, Indonesia. Child labour is illegal in Aceh. However, there is no enforcement of laws and regulations to prevent child labour from occurring and this daily phenomenon is escalating at an alarming rate. Furthermore, this research presents some complexities and paradoxes. While, the general assumption is that poverty is the main cause of child labour; however, this study found that children who are less poor are also working. Most of these children maintain their schooling while working. Consequently, some communities reject the impact of child labour on formal education. Many communities also see work as part of education, which teaches children responsibility, independence and self-esteem and/or pride, which represents the strong qualities of traditional Acehnese people, which has shaped the patterns and behaviours of children working in the region. The community's perspectives and other social polemics have continued the existence of child labour in Aceh. Therefore, Although it mights be not easy for the government to take actions, it is important to consider that the reduction of child labour programs in Aceh is not merely by strengthening the implementation of laws and regulations, but also requires the understanding of community values and attitudes around the issue.
\end{abstract}

Keywords: socio-cultural, Aceh, child labour, communities, education.

\section{INTRODUCTION}

The existence of child labour is not only a problematic issue in developing countries but also in wealthy countries (Schmitz, Traver\& Larson (eds.2004)). For example, Schmitz, Traver\& Larson (ibid) argued that in the United States, New Zealand, Australia and most of Western Europe the numbers of child labourers are increasing significantly due to the expanding definition of 'child labour'.

There are many definitions of child labour which change overtime. For example, Rogers \& Swinnerton (2008) stated that when the child labour issue first emerged, all forms of child labour were generally associated with child exploitation. However, in the 1990s the assumption changed, as some works conducted by children are potentially beneficial for children.

Moreover, this research investigated the 'socio-cultural' context of child labour in Aceh Province, Indonesia. The understanding of socio-cultural aspects aims to identify the background of the community's activities. Indeed, Friedland, Shaeff, \&Turnley, (2007) said, sociocultural studies of one community provide the outsider with the ability to have a deeper understanding of the researched community including what the community really needs. 
There are previous studies about child labour in Aceh, but none of these studies related to the socio-cultural context of the Acehnese. The Acehnese has uniquely formed by the long and challenging civil conflict that makes the socio-cultural life of Acehnese unique when compared to all other provinces in Indonesia.

Since August 2005, the Indonesian Government has granted Aceh to have the Special Autonomy Law, Act No. 18/2001 (SeuramoeInformasi Aceh 2001). The special autonomy allows the local government of Aceh to receive the income from natural resources is $70 \%$ for Aceh and $30 \%$ for central government (KBRICanberra 2001). This autonomy is expanded with the freedom to set out internal matters and reorganise local government, coherent with local customs and beliefs and the implementation of Shari'a Islam in Aceh (KBRI-Canberra 2001).

Furthermore, in understanding the child labour situation in Aceh, the humanrights issue cannot be separated from the socio-cultural life of Acehnese people. Therefore, this research is important that the socio-cultural study of the Acehnese community also will helps in understanding the reasons for why the number of child labourers is increasing, despite the extended laws and regulations. Is this due to the lack of commitment by government or are other factors including the social-cultures involved?

\section{LITERATURE REVIEW}

The definitions of child labour in Indonesia are more extensive. As mentioned by BPS \& ILO's (2009) survey, it includes the limits of working hours for children in different age ranges. Child labour applies to all children below eighteen years who are working. Indeed, the survey also mentioned that children aged 13 and 14 are classified as child labour if they are working for more than 15 hours per week or for more than 40 hours per week for children aged 15 to 17 years old. In addition, children aged below 12 years are included as child labour,regardless of how many hours they are working (ibid).

\section{The Socio-cultural Context of Child Labour in Previous Studies}

Some literature focused on sociocultural influences on child labour in certain countries. Social life, culture and religion are believed to affect the existence of child labour in many communities, besides poverty and lack of education Schmitz, Traver\& Larson (eds.2004); Friedland (2006).

A study conducted in India, for example, found significant cultural influence on child labour (Larson 2004). Larson (ibid) stated that the existence of child labour in India is commonly accepted; the caste system has rationalised that children from lower castes have less protection and are being more marginalised and often bound in labour forces to pay families' debt (Larson 2004). Similarly, in Iran, the culture of Iranians traditionally accepts the practice of child exploitation (Jalali 2004). However, the author noted that the percentage of child labourers in this country have decreased due to an increasing awareness of the impact of working on children and the importance of education for children. Nevertheless, progress is very slow as the social habits and traditions prevail and they are not easy to change (Jalali. ibid). Different from Indian and Iranian communities, Feldman \& Larson (2004) recognise Bangladeshi communities to have a belief that disallows children to work. However, these practices cannot be prevented because of economic need.

Discussing Africa in general, Oleribe (2007) argues that cultural belief shapes the primary attitudes of child labour in most African countries. Parents feel they deserve the support of their children because they have brought their children into the world and have taken care of them since they were infants, so it is time for the children to repay their parents by working. 
However, Moyo (2004, p.209) remarks: "in African societies, children are a blessing and a gift". Chinyangara et al. (in Moyo 2004) asserted that work for children in African cultures is acceptable, due to the belief that work teaches children to be responsible, understand the ethics of working and know how to respect the importance of working. Meanwhile, in Nigeria shows a similar acceptance of child labour (Ajayi \&Torimiro, 2004). Similarly, in Thailand, the culture of Thai people is considered the main contributing factor to the increasing numbers of child labourers (Sloan, 2004). Indeed, the implementation of law against child labour has not been strongly adopted by communities as child labour practices in Thailand are a strong tradition to help parents and considered to "pay back the breast milk" (Sloan 2004, p.178). The author also stated that working Thai children are not only from poor families but also from wealthier families.

Through the discussion above, we see the existence have been affecting by cultures in the countries and we see various perspectives on the value of child labour as evidenced in culture.

\section{RESEARCH METHODOLOGY}

The field study for this research used primary data from interviews and some secondary data sources including government and NGOs documents, books, organisation's websites and other online sources also some informal discussions with community and intellectual participants and field observations conducted.

Furthermore, the interview method used in this research was important for collecting data on the individual's interpretation of their conditions. The groups interviewed for this research are former child labourers, parents, village community leaders, government staff, community development workers and customary figures. Each group could give significant input for the research. As
Madden (2010, p.67) states: "interviewing does remain one of the most important ways of knowing others, for both ethnographers and many other types of data collector". By interviewing, we can gather information about individuals and their views that can be distinctive to others.

During the data collection process, this research received a lot of support from Pusat Kajian Perlindungan Anak (PKPA) or the Centre for Study and Child Protection's staff and management. Approaching and selecting community participants for this research began by coordinating with community leaders including the head of the village and the head of village social welfare. This coordination resulted in the list of participants for interview. The head of the village considered that these subjects could give relevant and reliable answers to the research questions.

This study interviewed 21 community participants including nine former child labourers, six parents of child labourers, four village community leaders and two employers of child labourers. The former child labourers mentioned in this research, who are more than 18 , were previously working when they were less than 15 years old. Furthermore, parents who participated in this research are those whose children worked when they were less than 15 years old. While, the community leaders suggested subjects for this research based on their positions as village officials and members of customary committees. (attached table).

Furthermore, in order for the research aims to be achieved, the two research's questions posed below become a guide to understand the socio-cultural context of child labour in Aceh (1). What are the socio-cultural context and community perceptions of child labour in Aceh? (2). How do Acehnese community perceptions affect the circumstances of child labour in Aceh? 


\section{DISCUSSION AND FINDINGS}

In 2005, the registered data for the number of child labourers in Aceh was 17,279 of 460,896 children aged 10 to 14 years (Save the Children, PKPA \& ILO 2009). Then, double in 2010, as mentioned by (DEPNAKERTRANS_RI 2010) that the BPS'ssurvey found 34.027 children in Aceh, aged 10 to 17 years,were considered child labourers. The total number for the same year in Indonesia was reported to be 3,260,701 (DEPNAKERTRANS_RI ibid).

The Indonesian Government's 2007/2008 census showed that most child labourers in Aceh work as hawkers, shoe polishers, in brick factories, fisheries and agricultural sectors (PKPA 2009a). In addition, PKPA (2009a) found that some children in Aceh are working in areas considered dangerous for children including beggars, scavengers, domestic workers, lobster divers,construction workers, drug trafficking and in marijuana plantations. However, in 2009, Ana Deonola, head of the child protection division of Save the Children, reported that there is no specific data on numbers of children working in dangerous zones in Aceh, as there wasa lack of research on child labour in Aceh (PKPA 2009b).

\section{Laws, Regulations and Child Labour Reduction Program in Aceh}

Related to law and regulation; the Indonesian Government has ratified the Convention Rights of the Child 1984 through presidential degree No. 36/1990; which define 18 years as children unless the law recognisesthat early maturity has been achieved (DEPSOS-RI 2008). Additionally, BPS \& ILO (2009) mentioned that the Indonesian Government has enforced the law No. 23/2002 on child protection that define children as everyone below 18 years.

KAN PBTA (2005) also notes that Indonesia is the first country in South-East Asia to ratify the ILO convention No. 138 through Law No. 20/1999. Indonesia has also ratified the ILO convention No. 182 through Law No 1/2000 (KAN PBTA 2005). A presidential decree No.12/2001 about the establishment of KomiteAksiNasional (KAN) or National Actions Committee is overcoming the worst forms of child labour (KAN PBTA 2005). In addition, there is also a presidential decree No.59/2002 about the formation of RencanaAksi National (RAN) or the National Actions Plan as the operational guidelinesfor the elimination of the worst forms of child labour in Indonesia (KAN PBTA 2005). Furthermore, KomiteAksi Aceh (KAA) or the Aceh Actions Committee, formed by the Aceh government, was based on the governor's decree No. 45/ 2009, as followup (Biro Hukum dan HumasPemerintahan Aceh 2010).

Additionally, the Aceh local government has enforced the Qanun law No.11/2008 on child protection and according to Angela Kearney, the UNICEF representative in Indonesia, this local regulation is in line with Indonesian law, with more detail on protection, and this regulation adopted children's requirements of the conflict and tsunami victims' children by other families (UNICEF Indonesia 2009).

KAA (2011) mentioned that children in Aceh who are over 18 years work legally. This is considered by KAA (2011) and pertains to the local government law, Qanun No. 5/2008, that compulsory learning for Acehnese children is from seven to 18 years, known as 12 years' compulsory learning. That regulation seems more advanced to that mentioned earlier as the regulation of age limitation in Indonesia in general; related to this, compulsory learning for children in Indonesia enacted in Law No. 20/2003 is from seven to fifteen years,known as nine years' compulsory learning. During compulsory learning, education is free in Aceh (KAN PBTA 2005). 


\section{Community Perspectives Challenge The Implementation of Child Labour Laws and Regulations in Aceh}

All participants, including parents and former child labourers interviewed in this research, are in doubt about the regulation that does not allow children below 18 to work. When asked about the law and regulations on the child labour issue, the most common answer from all community participants is that they "know a little bit about the regulation".

Moreover, Khairul, the community leader of the village (Interviewed, 28 November 2011) argued that people who employ children could be educated and would therefore be aware of the laws and regulations. Sometimes they might be government staff, or even people who fight for children's welfare. They are busy with their own work and they do not have time to do mundane jobs at home, so they employ children instead. Khairul further commented that this situation could lead children to be content, rather than being involved in the real work environment. However, he considered that works involving children in his village are not dangerous for children. Additionally, he said children in the village children are working to their ability. According to Khairul, sometimes he has to thank people who are hiring children, because it eases the burden on children and their families. $\mathrm{He}$ argued that all children who work in his village comefrom poor families and some have dropped out of school. Indeed, Khairul argued that he considered dropouts could cause social problems if they have no activities. This argumentation was also supported by Nursyidah, a parent participant (Interviewed, 2 December 2011), who acknowledged that she had suggested that her son work because he had dropped out of school and she was afraid he would become involved in crime, as the family were poor. "My son might need to buy or have things like other kids that I could not afford to provide [for] him; by working he can afford his wishes by himself, so [he] will not become a theft [sic]".

Meanwhile, employers have their own reasons as to why they employ children in their businesses. Ismail argues that heemployed children to accommodate them, as he considered they were unemployed. Mostly, children come from poor families and leave out of school. He argued that at least by working with him, the children are trained in practical skills. Besides, he confirmed that the children start work as labourers and they only do simple jobs, so they are capable.

However, he considered that if the children are diligent and willing to learn, they could have a skill that they could use for a better future.

"I pay them suitable [wages] with their work, based on their skill not based on their age. No force, I consider, if they do not work they will [be] out of control; Have nothing to do especially children who no longer at school. With me is the same like in the school, I train them. Although, only as a construction worker. ..." (Ismail, 4 December 2011).

He added that he never asked children to work with him, but the children came and asked for work. Similar to what was mentioned by a parent participant earlier, he stated that "instead the children become thieves to meet their needs, it is better if they work" (Ismail, 4 December 2011). From these similar arguments, community participants, who are also parents of child labourers, village community leaders and employers say that despite poverty, some children are better off working to avoid other dangerous social problems which lead to crime.

Moreover, none of the former child labourers gave reasons they had worked from an early age due to parental demands. However, all of them noted that they started working earlier, based on their initiative. The reasons that led them to work varied. They include helping their parents to support the family income; reducing the family burden by earning 
their own pocket money; taking responsibility; and the blissful feeling of having their own money to spend. Some also argued that circumstances where most of children are working and there was a demand for their labour, which encouraged them to work.

Besides these reasons, even government staff mentioned necessity or self-defence in negotiating the existence of child labour in Aceh;the Acehnese do not mean to harm their children. Therefore, during interview, most community participants used the term 'anak yang bekerja' or 'the children who are working'; rarely was 'pekerjaanak' mentioned or 'working children', and the term 'buruhanak' or 'child labour' was never mentioned. The first two terms mentioned above, suggest that children are working in an acceptable situation. In other words, the community sees the benefit of working for children.

\section{Acehnese Cultural Values and Attitudes Toward Child Labour}

There is a diversity of ethnic groups in Aceh; however, Acehnese ethnicity constitutes the majority of ethnic groups living throughout Aceh. This study focuses on the culture of Acehnese ethnicity. For Acehnese people, religion and culture is represented in their philosophic concepts known as naritmaja that "Adatngonhukom (agama Islam) lageizatngonsifeut". This saying means that the culture and regulations in Islam formed as a substance and essence (Badruzzaman 2010). The historical cultural civilization of Acehnese people is evident and influenced by Islam as the religion of majority Acehnese (Harun 2009). The naritmaja represents the way of life of the Acehnese community as well as an exemplary of Acehnese life (Harun ibid). Indeed, Harun (2009) stated that the character of Acehnese people are resilient, tough and brave, in naritmaja, which is:

Meunyomeuheuttapajoehbu, tatheundeuekdilee
Meunyo kaya tameunabsu, tahareukatdilee This narit means people who want to pursue their happiness should be ready to face all challenges and obstacles for their success. These considerations also embrace Aceh's younger generation who have learnt to be strong and avoid being dependent.

In general, Aceh is known as the Islamic region in Indonesia (KBRI Canberra 2001). Islam is very important in Aceh; however, related to child labour, Islamic teaching neither supports nor prohibits children to work. In Islam, children are entrusted to their parents. Therefore, parents are responsible for this trust on moral and ethical grounds and for the education of their children (Anshori 2009), stated in the Qur'an (QS. AlBaqarah: 233). The Qur'an also mentioned that children have a responsibility to give good treatment to their parents (QS. AlAhqaf: 15). Anshori (2009) argues that children have a responsibility to care for their parents.It is more about the compassion of children for their parents.

Furthermore, the relationships between parents and children in Aceh culture, as stated by Badruzzaman (2010, p.1) and expressed in many naritmaja is:

Jakkutimangbungongmeulu, gantoeaburayeukgata

Tajakmeugoengoen ta mu'u, mangatnabu ta brie keu ma

This saying explains how parents have expectations for their children's future and that children will look after their parents when they become elderly (Badruzzaman 2010). However, it is important to note that in this naritmaja, children are expected to contribute when they become "rayeuk" or adults. The age of the childrenis not mentioned when they are needed to support the family in saying.

Meanwhile, working to help parents for Acehnese children is implicit in naritmajaand passed on from generation to generation:

Keu peusietnaaweuk, Keunbektutongjaroe Keu peusietnaaneuk, Keunbekpayahdroe 
The first sentence of the above saying is the spoon to avoid burning the hand. The second sentence means having children to reduce the difficulty for parents (Ilyas 2010). In general, the first sentence is only a metaphor, but the message of the saying is in the last sentence. Related to this saying, Ilyas (2010) argued that for Acehnese children, working refers to an expression of their love for their parents, rather than a form of exploitation. Indeed, children in Aceh are expectedto work, which is a lesson to prepare children for their future.

\section{The Paradox of Child Labour in Aceh}

The paradoxical issue of child labour in Aceh is consideredby most participants including government staff, community development workers, customary figures, parents of child workers, child employers and former child labourers as a necessity to get out of poverty. This research also reveals that not all working children come from poor families. Furthermore, the paradox of child labourcanbe found in the educational context. The findings from this research reveal that working affected children's education as well ascouldmaintainboth work and participate at school.

Likewise, both the Indonesian Government and the Aceh local government have enacted laws and regulations in order to reduce the number of child workers, while the cultural context supports child labour. In Aceh, there is also the belief that children have to be protected from any form of violence (Ilyas 2010). Unfortunately, however, research shows that children are involved in work that does harm them. This chapter investigates the child labour issue in Aceh that paradoxically has existed as a common practice by looking at the sociocultural framework including poverty, education access and cultural perspectives.

In this research, a parent participant, Rosmawar (Interviewed, 6 December 2011) acknowledged that her children have been working from an early age; the oldest child'seducation was not even primary level and he has worked in a brick factory since primary school. However, she has a daughter who worked with her in a catering business, who has continued her schooling and is now a university student. Other children only completed secondary school. Rosmawar stated that her sons who graduated from secondary school used to work to help neighbours, doing gardening and helping on their farms. Now they are both construction workers. She argues that her children are working because she is poor and her husband is jobless and sick.

Rosmawar mentioned that her son was at school, but the neighbours often asked help to work in their gardens or on their farms and gave them money, so they were happy working and did not want to continue their school. The community around her knows her family's economic situation. That is why the neighbours did not hesitate to ask her children to do something for them to enable them to give money to the children.

Furthermore, she confirmed that she could not afford to give her children pocket money. "My children are working for their own pocket money, and sometimes they give [the money to] me to use the money for family's needs". Similar to Rosmawar, whether the children continue with their schooling or not, most parents and village community leaders argued that children from their village are working for their own pocket money.Therefore, they would not ask for money from their parents, which their parents could not afford to give.

This research also found that children from wealthy families were attracted to work. Khalid's case study is an example. Khalid, a 25-year-old former child labourer and his father, Kasim were separately interviewed for this research. Khalid (Interviewed, 5 December 2011) acknowledged that he and some of his brothers were construction workers when he was approximately twelve years old 
because most of his peers from the village were working. Khalid considered that work was the place to stay with his friends and gain skills that he could use to supervise people who built his house, even though he isno longer a construction worker. He agreed that construction work seems like heavy work because children have to carry heavy stuff or work on the second or third floors of buildings without safety equipment, but for him it was not a problem.

His family was regarded as high economic level by the other villagers because his parents had big farm compared to most of the other villagers. However, he and his brothers were happy to work to have their own money to spend. He assumed that his parents did not know he was working when he was young. In villages in Aceh, children used to play with other children their age without parental supervision. Therefore, when Khalid and his brothers were busy working, his parents worked long hours and thought the children were playing with their friends.

When Kasim (28 November 2011), was interviewed, he confirmed that his children only worked to help him on his farm. "None of my children worked for money. When they were kids they only worked on our farm and they only did simple work, such as collecting snails and clearing the bush, whether they worked or not if they needed I gave them pocket moneys"

However, for farming parents including Kasim, who works hard to earn money, they will be very wise in using the money. Those parents will only buy things for their children if they consider that as needs. Meanwhile, children like Khalid could have the desire to own something that his parents would not buy for him. By working, he could afford those things by himself as well as his other peers. Besides, the necessity of being with friends in the social life of Acehnese children and peer influence leads children to work; however, peer pressure results in material aspirations that in turn lead Khalid to want to have his own money as well as his friends. Thus, not all children who are working come from poor families; however, where children from wealthier families also work, it is because the circumstances where most children are working and there are number of available workplaces provide opportunities for children to work.

From education access perspective, the community sees the possibility for children to have better education is related to family income. For example, Rosmawar's sons and Khalid worked in the same sector as children; however, Khalid was able to access better education while Rosmawar's sons were not.

From culture perspective, these both case studies showed characteristics of Acehnese people. For Rosmawar's son, even though they are poor, he would not beg. Therefore, they work to avoid begging. Meanwhile, Khalid's strong characteristic was to be independent; even though his parents were able to support him financially, he preferred to work and earn his own money to avoid to be only parents' dependent.

Furthermore, the case of Rosmawar's son that often work for better income neighbours similar to PKPA's earlier research on children working as domestic workers in Aceh, in Acehnese, the term 'domestic worker' was replaced by the term 'tolong-menolong' or 'mutual help' (Manik 2008).

Moreover, a case study discussed below also shows a picture of a family who consider their children highly responsible. Nurlaili, 23 years old (Interviewed, 3 December 2011) is a former child labourer who works forher family's business, owned by her parents, making kueh karah. She helps the business along with her other five sisters. Three of them are married but still contribute to the business. Nurlaili is the oldest daughter in her family. 
She started working when she was about 8 to 10 years old, but she said when she was little she had a few simple duties and then took on more responsibility as her capabilities improved. She agreed with other community participants who said that children working in her village are not exploited, but work within their capabilities.

She argued that she did not feel forced to work, and she was proud to have the skills to make kueh karah that not everyone knows how to make it. However, she acknowledged they could work until late at night to complete the consumers' orders. She noted this business was profitable; approximately five million rupiah per month and her mother kept all the money. She and her siblings only asked for money from their parents if they needed pocket money.

She did not agree that work affected children's school participation. To prove her argument, she gave an example from her own family.Six children had started working from a very early age, doing the same work; however, they dropped out of school at various times, for their own specific reasons. She had studied for diploma, but did not complete it, due to the need to look after her son after she married. Her youngest sister graduated from primary school and did not continue with study. Moreover, three other sisters graduated from junior high schools and one other graduated from high school. She argued that her younger sister quit school early because she did not like school: "she was not doing well in her school", she said. She acknowledged that her younger sister continued to have repetition.

Yusuf as a parent does not want to harm his children. However, parents like Yusuf might consider that his daughters; especially the youngest one, has had to repeat her education many times because she is not smart enough to be at school. He might considerhis daughter's own limitations in study. Did he realise, for example, that the work the daughter does makes her too tired to start the day at school because she is working late nights to fill the orders?

Meanwhile, the youngest daughter, due to repeating her schooling, potentially is the oldest child in her class. This might exacerbated when her teacher and school friends in her class thought she was a stupid girl. While she, herself, did not know why she was unable to compete with her classmates, or why she felt sick and tired, and wanted to leave the classroom to go home and sleep. This situation could worse if the teacher found her asleep or if she had not finished her homework or could not absorb the class lesson.

She may be aware that she felt sleepy because of her late nights filling consumers' orders. Especially, after finishing her kueh karah responsibilities and realising that there is still homework to be done or examsthe next day. This paradox from the poverty perspective also shows that poverty is not always the cause of child labour.Working can be regarded as a good prospect for children, by giving them skills and knowledge for the future.

This paradox from an education perspective shows that communities might not be aware of the impact of working on children's education. As well as the case study of Rosmawar's son and Khalid, children who work in the same sector, such as Nurlaili and her sisters, have different levels of educational achievement. This polemic weakens the relation of work to education access. However, from this research, investigations show that children like Nurlaili's sister suffer at school due to her other responsibility,helping run her family's business.

The child labour situation in Aceh is very complex. In addition to poverty, there is lack of awareness of the importance of and access to education; there are also other issues such as corruption, nepotism and lack of public trust of the government, which compound these issues.

A case study of Faisal, a 28-year--old former child labourer, shows the 
complexity of these issues. Faisal (Interviewed, 24 November 2011) confirmed that even though he worked from an early age, he finished his high school. He considered that he could not finish his high school education if he did not work, as his parents were poor, and he is the oldest in a family of six siblings. He started part time as a construction worker when he was about seven years old. Then, he worked as a carpenter after he was 15 . His mother did not ask him to work, but he considered he had a responsibility as the oldest boy in his family. The money he earned from working enabled him to keep pocket money and give the rest to his mother to support his family.

His dream was to be a police officer, but he considered thiswas an impossible dream for poor people. Therefore, he said he stopped dreaming and continued working as a labourer. Faisal realised that university was not far from where he lived; however, university study was not related to his dream. He worried that he could not manage his work and study time at university, because the university timetable was unpredictable. Indeed, working at an earlier age enabled Faisal to finish high school, but the lack of any further education excluded him from nonlabouring employment. He remains a labourer however he believes that working as a child gave him a chance to finish high school.

However, the public distrust of government has buried ideals and dreams such as Faisal's; therefore, many children like Faisal quit school because education cannot achieve their goals. As a consequence, they leave school so they can receiveon-the-job skills and experience for their future. Was it the education system or the parental systemthat failed? What are the real needs of the community and the children? Faisal did not see the benefits of formal education, which he considered could not fulfilhis dream. He did not see either that work limited his access to further education, because the decision not to continue his schooling was his own decision.

Therefore, instead of regulation to forbid children to work, the encouragement of communities, parents and children about the benefits of being educated is the best way to inform them of the downside of child labour. In his opinion, children will also learn about their rights at school. For that, government should also consider campaign and implementation to eradicate corruption and nepotism in job recruitment that has been doubt for many years within local communities.

\section{CONCLUSION}

Child labour is illegal in Aceh and the Indonesian Government has ratified the international conventions regarding child labour. There are also national and local government laws and regulations in place to protect children from exploitation in working in the fields. However, there are children in Aceh working in areas considered as dangerous for children (PKPA 2009a). This research found that most children working in the village are construction workers, and there are also children working in rice mills, brick factories and home industries. The works that by most of research participants are considered do not harm children health and educations from this research brought some potential drawbacks.

Moreover, this study reveals that the community do not received information of the laws and regulations on child labour and therefore the practice is widespread. None of child labour actors in Aceh has received sanctions so there is no law enforcement. In fact, children in Aceh are working in the public sphere. Regarding the socio-cultural framework, in general, child labour in Aceh has similar features to those in others places where child labour exist. Poverty, lack of education access, and cultures that accept child labour in certain countries are the main contributing factors to children working in Aceh. In 
Aceh (KAA 2011; PKPA 2009b), besides poverty and lack of access to education, the acceptable of children to involve in working sector in Acehnese community increase the number of child labourers in Aceh.

In one way, conflict shapes the Acehnese who are used to dealing with difficult situations; however, the strong belief of the existence of God and Islam has influence over the people who avoid doing anything that is forbidden in Islam. They tend to obey Allah's command, which includes parents and children who have mutual responsibilities. Anshori (2009) mentioned that parents' responsibilities in Islam are moral and ethical, including the education of their children,whereas children need to look after their parents. In relation to Islam and child labour, neither Islam neither supports nor forbids children to work. Related to the relationship between parents and children, this research presented that child labourer in Aceh tend to use the money they earn to reduce family financial problems and this is realised as compassion towards their families. The PKPA (2009c) also supports this finding.

From the education perspective, even though the BPS data shows that attendance at school in Aceh was relatively high, and that most possibly most children were both working and attending school, similar to the situation in some parts of the world as mentioned by World Bank in Schmitz, Traver\& Larsoneds.2004). Meanwhile, community participants including some former child labourers, village community leaders and parents argued that droppingout of school or not working depended on whether children wanted to study.

In contrast, this research shows that working evidently affects children's school participation rates. This finding is especially related to the working hours of children, although they are not working during school time; however, working affected their time to rest and focus on their studies. Moreover, this research also shows that some parents were not aware that working affected their children's school participation. Parents whose children dropped out early from school considered that their children dropped out because they did not want to attend school. From community understanding, there are some factors that lead children from poor families to quit school: they are pressured and feel uncomfortable at school,they feel inferior in school due to peer pressure and material aspirations and finally the high costs and poor quality of education. A child who worked for their parent's business dropped out early from school because she had to keep repeating her education and her parents thought she did not like school. In fact, this study found that she often worked until late at night and most possibly led her to be too tired to concentrate in the classroom this conclusion similar to what stated by the ILO (2002).

This research also found that working children in construction sector and rice mills were doing heavy lifting,are considered by former child labourers, parents and village community leaders as work that children are capable of doing. The earlier comments by Manik (Interviewed, 17 November 2011) reveal that children who work as lobster divers become deaf or hearing impaired; however the community considered the children were capable of diving. Additionally, this research reveals that the culture in Aceh did not determine a sex preference in order to decide whether children would attend school or work, different to what was mentioned by Wang (2005), which occurs in China and in Ethiopia (Alvi\&Dendir, 2011_. It is evident that the involvement of working children in Aceh varies, as both boys and girls work and attend school. Furthermore, as previously mentioned, the decision to work or access education for children from poor families was often made by the children and parents do not forbid their children from working because 
they see work as a solution for financial problems.

Furthermore, this research also revealed that the social life of the Acehnese, which has a strong social relationship and kinship,also has strong connections between parents and children. There is no caste system in Aceh that could influence the numbers of working children, as mentioned by Larson (2004) in India; however, strong relationship and kinship also provide the opportunity for people from better financial incomes to employ children from poor families. Nevertheless, for the Acehnese, this employment is considered mutually beneficial, because people who are better off financially need people to help them and people who are poor need money to survive.

Another finding from this research is that peer influence and pressure also cause children who are not poor to work. As children need to be with their friends they see work as the place where they have more time to be with their friends. Additionally, working also provides them with money, so they do nothave to ask their parents. Meanwhile, some parents might not be aware that their children are working because they in turn are too busy working, and consider their children are playing with friends.

The strong connection between parents and children also lead children to work to help their parents. The culture in Aceh in the literature mentioned working as the responsibility of children to help their parents. Sloan (2004) also argues that the culture of Thai children is to work as payback for breast milk. However, this culture does not mention the age of children to have such responsibility; however, parents are giving children responsibilities that match their capabilities.

Besides the need to increase parental and community awareness of the importance of education; cooperation from the schools is needed to avoid children dropping out in future. This means that teachers and parents will be more cooperative about children's achievements and weaknesses in their studies, and teachers need to be more aware of the possibilities of children dropping out because they are working, or have other activities that distract their concentration. A more cooperative approach will result in early detection and enable parents and teachers to work together to prevent children dropping out.

As mentioned by the ILO (2002), not all work needs to be eradicated for children, especially work that involves knowledge transfer from parents to children. In the case of Aceh, the government and community development workers who are concerned about the children's welfare need to encourage community awareness of the impact of working on children. Some work considered compatible could harm children, mentally and physically. Government and community development workers need to have a better understanding of how work affects children, and differentiate between socalled light work and dangerous work for children.

In conclusion, working Acehnese children means being dependent and being able to spend money, without having to beg from others including parents. Working for Acehnese children is a way out of poverty and they are brave, tough and resilient. Working for Acehnese children is mutually beneficial for employers and child labourers: employers receive help and the children receive money. Working for Acehnese children means time to socialise with friends because friends are also working. However, for some children, works impedes their educations and harms their health. That situation requires action to communicate and inform the community that working impacts on children. The existence of laws, regulations and other programs to improve children's welfare 
and wellbeing must be based on community respect, belief and understanding. Importantly, the government should encourage communities to be more aware of the importance of education by also build up the communities' trust on job recruitments especially in the government's departments or institutions.

\section{REFERENCES}

Ajayi, AO \& Torimiro, DO. 2004. Perspectives On Child Abuse And Labour: Global Ethical Ideals Versus. African cultural realities, Early Child Development and Care, Vol. 174(2), pp. 183-191, viewed 2 July 2011.

Alvi, E \& Dendir, S. 2011. Sibling Differences In School Attendance And Child Labour In Ethiopia. Vol.39, London, Routledge

Anshori, I. 2006. Perlindungan Anak Dalam Agama Islam. Jakarta Pusat, Komisi Perlindungan Anak Indonesia

Badruzzaman, 2010. Mengemis dalam Budaya Masyarakat Aceh. Banda Aceh, Majelis Adat Aceh

Biro Hukum dan Humas Pemerintahan Aceh. 2010. Peraturan Gubernur Aceh, Nomor. 45 Tahun 2009, tentang Komisi Pekerjaan Terburuk Untuk Anak. Biro Hukum dan Humas Pemerintahan Aceh. Banda Aceh, viewed 18 August 2010, (http://www.infohukum.nad.go.id/kata log/fileproduk/P45\%20Bentuk\%20Ter buruk\%20Anak.pdf)

BPS .2011. Persentase Penduduk Miskin Menurut Kabupaten/ Kota, Provinsi dan Nasional (\%). BPS Aceh, Banda Aceh, viewed 7 June 2012 (http://aceh.bps.go.id/index.php?optio $\mathrm{n}=$ com_wrapper\&view $=$ wrapper\&Ite $\operatorname{mid}=112$ )

BPS \& BAPPEDA, 2005, Aceh Dalam Angka-Aceh in Figure 2005. Banda Aceh, BPS \& BAPPEDA Provinsi Aceh
BPS \& BAPPEDA, 2010. Aceh Dalam Angka-Aceh in Figure 2010. BPS \& BAPPEDA Provinsi Aceh, Banda Aceh.

BPS \& ILO .2009. Pekerja anak di Indonesia 2009. Badan Pusat Statistik \& Organisasi Perburuhan Internasional, catalogue BPS 2306002, ISBN. 978-979-064-144-0, Publication no. 04120.1003, Jakarta

DEPNAKERTRANS-RI. 2010. Pekerjaan aku umur 10-17 tahun di Indonesia, Kemetrian Tenaga Kerja dan Transmigrasi Indonesia, Jakarta, viewed $12 \quad$ March 2012 (pusdatinaker.balitfo.depnakertrans.go .id/katalog/xdownload.php?f...)

DEPSOS-RI. 2008. Pedoman Peringatan Hari Anak National Tahun 2008, Departemen Sosial RI, Jakarta, viewed 15 February 2011, (http://www.google.co.id/url?sa=t\&rct $=\mathrm{j} \& \mathrm{q}=$ pedomanperingatan+hari+anak \&source $=$ web\&cd $=2 \&$ ved $=0$ CE0QFj AB\&url=http\%3A\%2F\%2Fwww.deps os.go.id\%2Fmodules.php\%3Fname $\%$

3DDownloads\%26d_op\%3Dgetit\%261 id\%3D47\&ei=tXcBUNeXJIiQiQfr78j 8Bw\&usg=AFQjCNEDhQSz0CtH88Y0PfMEgBhaWH9ow\&cad=rj)

DINSOS Aceh. 2010. Rekap PMKS Perkabupaten Kota Tahun 2009/2010. Banda Aceh, Dinas Sosial Aceh

Feldman, S \& Larson, D. 2004, Bangladesh' in Schmitz, CL, Traver EK \& Larson, D (eds.) 2004, Child Labour: a global view, 1stedn. London, Greenwood Press, pp. 13-25

Friendland, LE. 2006. Socio cultural Perspectives: A New Intelligence Paradigm, MITRE (Center For National Security Programs), Virginia, viewed 26 may 2012, (http://www.google.com/url?sa=t\&rct=j\& $\mathrm{q}=$ sosiocultural $\% 20$ include $\&$ source $=$ web $\& \mathrm{~cd}=7 \&$ ved $=0 \mathrm{CGEQFjAG \& url=http} \% 3$ $\mathrm{A} \% 2 \mathrm{~F} \% 2 \mathrm{Fwww}$.mitre.org\%2Fwork\%2Ft ech_papers\%2Ftech_papers_08\%2F07_1 220\%2F07_1220.pdf\&ei=vfq_T8_dJoezi Qfa12_Cg\&usg=AFQjCNGJD740CsohN sGwfWJcFWnUnISzrQ\&cad=rja) 
Friedland, LE, Shaeff, GW, Turnley, JG 2007. Sociocultural Perspectives: A New Intelligence Paradigm - Report On The Conference at MITRE Corporation, MITRE (Center for National Security Programs), Virginia, viewed 26 may 2012 (http://www.google.com/url?sa=t\&rct $=\mathrm{j} \& \mathrm{q}=$ sosiocultural $\% 20$ include $\&$ sourc $\mathrm{e}=$ web\&cd $=7 \&$ ved $=0$ CGEQFjAG\&ur $\mathrm{l}=\mathrm{http} \% 3 \mathrm{~A} \% 2 \mathrm{~F} \% 2 \mathrm{Fwww} . \mathrm{mitre}$. org $\%$ 2Fwork\%2Ftech_papers\%2Ftech_pap ers_08\%2F07_1220\%2F07_1220.pdf \&ei=vfq_T8_dJoeziQfa12_Cg\&usg= AFQjCNGJD740CsohNsGwfWJcFW nUnISzrQ\&cad=rja)

Harun, M. 2009. Memahami Orang Aceh. Bandung, Citapustaka Media Perintis, 1 st ed.

Hasan, J. 2010. An Assessment Of Child Labour Laws, Prevention Strategies And Their Effectiveness In Bangladesh' In Herath, $G$ \& Sharma, $K$ (Eds.), Child Labour in South Asia. Hamsphire, Ashgate Publishing Limited, pp. 81-98

ILO. 2002. Menanggulangi Pekerja Anak: Panduan Untuk Pengawas Ketenagakerjaan. Jakarta, Organisasi Perburuhan International \& Departemen Tenaga Kerja dan Transmigrasi Republik Indonesia, .

ILO. 2005. After The Tsunami Preventing Child Exploitation In Aceh. Geneva, Switzerland,ILO, viewed 15 August 2010

(http://www.oit.org/global/About_the _ILO/Media_and_public_information/ Feature_stories/lang-en/WCMS_075557/index.htm)

ILO. 2010,. Laporan Global ILO Terbaru Mengenai Pekerja Anak: Upaya Untuk Menghapuskan Pekerja Anak Melambat, ILO Menyerukan Untuk "Menguatkankembali" Aksi Global, ILO, viewed 6 May 2012,(http://www.ilo.org/jakarta/info/ public/pr/WCMS_126979/lang-en/index.htm)
ILO .2011. Hari Dunia Menentang Pekerja Anak: Awas! Anak-Anak Di Pekerjaan Yang Berbahaya- Stop Pekerja Anak!, ILO, viewed 6 May 2012

(www.ilo.org/jakarta/info/public/pr/W CMS_157695/lang--en/index.htm)

Ilyas, M. 2010. Sosbud: Stop Buruh Anak Aceh. Medan, Kompasiana, 13 July 2010, viewed 15 September 2010, (http://sosbud.kompasiana.com/2010/ 07/13/stop-buruh-anak-di-aceh/)

Jalali, R. 2004. Iran in Schmitz, CL, Traver EK \& Larson, D (eds.) 2004, Child Labour: a global view, 1stedn, Greenwood Press, London, pp. 113122

KAA. 2011. Penghapusan Bentuk-Bentuk Pekerjaan Terburuk Untuk Anak Laporan Pendataan \& Pemetaan Bentuk-Bentuk Pekerjaan Terburuk Untuk Anak. Banda Aceh, KAA

KAN PBTA. 2005. Laporan Pelaksanaan Rencana Aksi Nasional Penghapusan Bentuk-Bentuk Pekerjaan Untuk Anak. ILO, Jakarta, viewed 22 July 2011, (http://www.ilo.org/wcmsp5/groups/p ublic/---asia/---ro-bangkok/---ilojakarta/documents/publication/wcms_ 123823.pdf)

KBRI Canberra. 2006. Undang-Undang Republik Indonesia No 11 tahun 2006: Tentang Pemerintahan Aceh. Jakarta, 11 August 2006, Canberra, viewed 24 June 2011, http://www.kbricanberra.org.au/s_issues/aceh/regulasi /UU\%20Aceh.pdf

Larson, D. 2004. India in Schmitz, CL, Traver EK \& Larson, D (eds.) 2004, Child Labour: a global view, 1stedn, Greenwood Press, London, pp.101111

Lavalette, M, Cunningham, S. 2004, Globalisation and Child Labour: Protection, Liberation or Anti Capitalism, in Munck, $\mathrm{R}$ 2004, Labour and Globalization: Results and Prospects, Liverpool, Liverpool University Press 
Madden, R. 2010. Being Ethnographic: A Guide To The Theory And Practice Of Ethnography. London, Sage Publications Ltd.

Manik S .2008. Anak: Dibantu Atau Pembantu: Temuan Penelitian Pekerja Rumah Tangga Anak (PRTA) Perempuan Di Kota Banda Aceh Nanggroe Aceh Darussalam., Banda Aceh, PKPA

Moyo, O. 2004. Zimbabwe' in Schmitz, CL, Traver EK \& Larson, D (eds.) 2004, Child Labour: a global view, 1 stedn, Greenwood Press, London, pp. 199-212

Oleribe, OE. 2007. Exploring The Causes of Child Labour Series, International NGO. Academic Journals Article, Journal Vol. 2 (1), pp. 006-009, January 2007, viewed 22 July 2011, (http://www.academicjournals.org/ing oj/pdf/Pdf2007/Jan/Osita-Oleribe.pdf)

PKPA. 2009. Pekerja Anak di Aceh. Banda Aceh, PKPA, viewed 10 September 2010, (http://pkpaaceh.blogspot.com/2009/pekerja-anakdi-aceh.html)

PKPA. 2009. Belasan Ribu Anak Aceh Bekerja Bantu Orang Tua. Banda Aceh, PKPA, viewed 18 August 2010. (file:///G:/ICD/ComDev\%20Theory\% 20and\%20Practice/Children\%20Labor /belasan-ribu-anak-aceh-bekerjabantu.html)

Rogers, CA \& Swinnerton, KA. 2008. A Theory Of Exploitative Child Labor. Oxford Economic Papers, viewed 17 July $2011 \quad$ (http://0oep.oxfordjournals.org.library.vu.edu. $\mathrm{au} /$ content/60/1/20.full.pdf+html?max toshow $=\&$ hits $=10 \&$ RESULTFORMA $\mathrm{T}=1 \&$ title $=\mathrm{A}+$ theory + of + exploitative +child+labor\&andorexacttitle $=$ and \&a ndorexacttitleabs=and\&andorexactfull text=and\&searchid=1\&FIRSTINDEX $=0 \&$ sortspec $=$ relevance $\&$ resourcetype $=$ HWCIT)

Save the Children, PKPA \& ILO. 2009. Pekerja Anak di Aceh. United to
Protect children, Tajoek Ruweungkeuaneukinong, Banda Aceh, Save the Children, PKPA \& ILO

Schmitz, CL, Traver EK \& Larson, D (eds.). 2004. Child Labour: A Global View. 1stedn, Greenwood Press, London

Seuramoe Informasi Aceh. 2001. UndangUndang Republik Indonesia, Nomor 18 Tahun 2001: Tentang Otonomi Khusus Bagi Provinsi Daerah Istimewa Aceh Sebagai Provinsi Nanggroe Aceh Darussalam. Banda Aceh, Seuramoe Informasi Aceh, viewed 24 June 2011, http://www.seuramoe.acehprov.go.id/ wp-content/uploads/2009/12/uu-no18-th-2001.pdf

Sharma, K. 2010. Trade, Growth And Child Labour Practices In South Asia' In Herath, $G$ \& Sharma, $K$ (Eds.), Child Labour In South Asia. Hamsphire, Ashgate Publishing Limited, pp. 65-77

Sloan, L. 2004. Thailand in Schmitz, CL, Traver EK \& Larson, D (eds.) 2004, Child Labour: a global view, 1stedn, Greenwood Press, London, pp.175184

Traver, EK. 2004. Brazil in Schmitz, CL, Traver EK \& Larson, D (eds.) 2004, Child Labour: a global view, 1stedn, Greenwood Press, London, pp. 27-38

UNICEF Indonesia. 2009. Penguatan Perlindungan Bagi Anak-Anak Berdasarkan Islam. Jakarta, UNICEF, viewed 22 July 2011, (http://www.unicef.org/indonesia/id/m edia_12925.html)

Usman, AR. 2003. Sejarah Peradaban Aceh. Jakarta, Yayasan Obor Indonesia

Wang, W. 2005. Son Preference and Educational Opportunities of children in China "I wish you were a boy!", Gender Issue, Spring 2005. Retrieved from Academic Research Premier, viewed 12 June 2012. 


\section{ATTACHED TABLE}

Table 1. Demographic Of Community Participants By Gender, Age And Education

\begin{tabular}{|l|c|c|c|c|c|c|c|c|c|}
\hline \multirow{2}{*}{ Research subjects } & \multicolumn{2}{|c|}{ Gender } & \multicolumn{3}{|c|}{ Age range } & \multicolumn{3}{c|}{ Education } \\
\cline { 2 - 10 } & Male & Female & $\begin{array}{c}18-35 \\
\text { years }\end{array}$ & $\begin{array}{c}36-45 \\
\text { years }\end{array}$ & $\begin{array}{c}45+ \\
\text { years }\end{array}$ & $\mathrm{a}$ & $\mathrm{b}$ & $\mathrm{c}$ & $\mathrm{d}$ \\
\hline $\begin{array}{l}\text { Former child } \\
\text { labourers }\end{array}$ & 5 & 4 & 9 & - & - & - & 2 & 3 & 4 \\
\hline $\begin{array}{l}\text { Parents of child } \\
\text { labourers }\end{array}$ & 3 & 3 & - & 4 & 2 & 5 & - & 1 & - \\
\hline $\begin{array}{l}\text { Village community } \\
\text { leaders }\end{array}$ & 3 & 1 & 2 & 1 & 1 & - & - & 1 & 3 \\
\hline $\begin{array}{l}\text { Employers of child } \\
\text { labourers }\end{array}$ & 1 & 1 & - & 2 & - & - & - & 2 & - \\
\hline
\end{tabular}

*a: primary: 7-12 years old, b: secondary: 13-15 years old, c: high school: 16-18 years old, d: technical diploma/university: $18+$ years old 